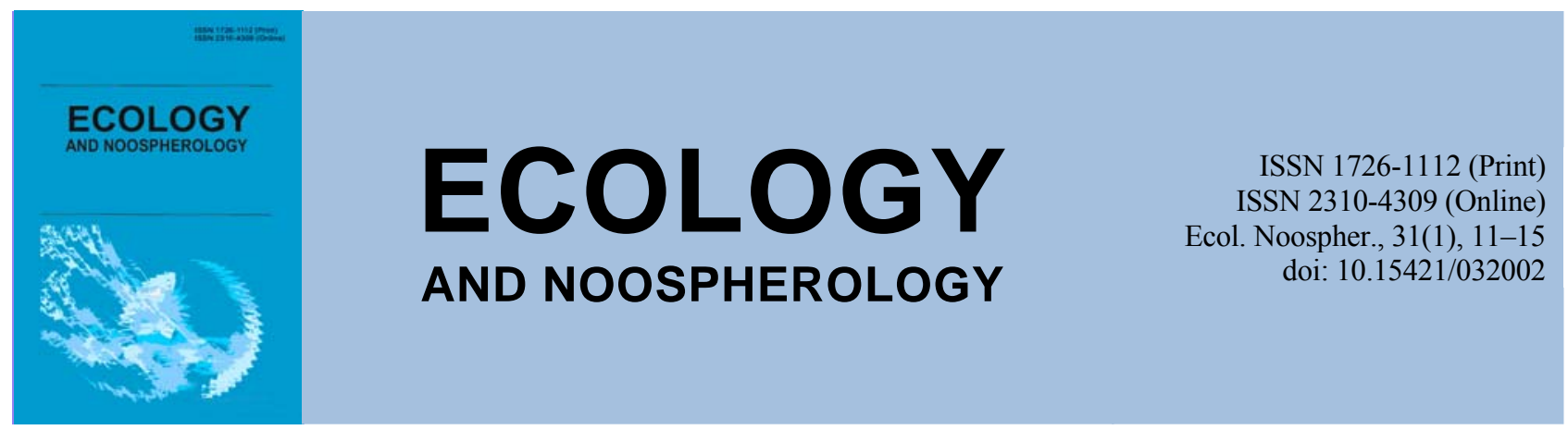

\title{
Assessment of the impact of horse-chestnut leaf miner (Cameraria ohridella Deschka \& Dimič, 1986) on photosynthesis of common horse chestnut (Aesculus hippocastanum Linnaeus, 1753)
}

\author{
K. K. Holoborodko, A. A. Alekseeva, O. V. Seliutina, V. A. Gorban \\ Oles Honchar Dnipro National University, Dnipro, Ukraine
}

Article info

Received 22.06.2020

Received in revised form 29.06.2020

Accepted 05.07.2020

Oles Honchar Dnipro

National University,

Gagarin Ave., 72, Dnipro, 49010, Ukraine.

Tel.: +38-066-795-63-20

E-mail: goloborodko@ua.fm
Holoborodko, K. K., Alekseeva, A. A., Seliutina, O. V., \& Gorban, V. A. (2020). Assessment of the impact of horse-chestnut leaf miner (Cameraria ohridella Deschka \& Dimič, 1986) on photosynthesis of common horse chestnut (Aesculus hippocastanum Linnaeus, 1753). Ecology and Noospherology, 31(1), 11-15. doi:10.15421/032002

The article presents the results of studies on Cameraria ohridella Deschka \& Dimič, 1986 feeding on the state of the photosynthetic apparatus in Aesculus hippocastanum Linnaeus, 1753. The studies were carried out in June 2019 (during the life of C. ohridella first generation) on the territory of the Botanical Garden of the Oles Honchar Dnipro National University. Photosynthesis is one of the processes most susceptible to stress factors; important information on state of the photosynthetic apparatus in plants under influence of various abiotic and biotic factors can be obtained by fluorescence analysis. Chlorophyll fluorescence is an indicator that allow to investigate a behavior of photochemical reactions related to system II (PSII) in living objects as an indicator the most sensitive to effect of environmental factors. One of the effective methods for plant state monitoring is a technique on chlorophyll fluorescence induction (CFI) measurement, which at the present stage can be introduced due to the use of biosensors. The objective of our study was to establish characteristics of $C$. ohridella vital activity on the photosynthesis process in $A$. hippocastanum trees using CFI evaluation technique. To diagnose photosynthesis violation of native chlorophyll in a living leaf of A. hippocastanum, we used a portable fluorometer "Floratest" (spectral range for measuring fluorescence intensity 670 to $770 \mathrm{~nm}$ ) developed by V. M. Glushkov Institute of Cybernetics of National Academy of Sciences of Ukraine. The studies were conducted using alive $A$. hippocastanum leaves not damaged by $C$. ohridella and, accordingly, the damaged ones. Analysis of the data obtained showed that the worm feeding affects all CFI parameters (initial CFI value (nondamaged leaf: 582 relative units, damaged: 264); "plateau" CFI value (1460 to 722); maximum CFI (1890 to 940$)$ and stationary CFI value after light adaptation of the leaf (1530 to 746$)$ ). Our studies have shown that CFI technique using "Floratest" apparatus allow express determining the general condition of the plant by assessing the main process of vital activity, namely photosynthesis. Analysis of chlorophyll fluorescence parameters is a powerful and effective tool for determining the phytophage effect on the plant.

Keywords: influence of invasive species; Cameraria ohridella; Aesculus hippocastanum resistance; intensity of chlorophyll fluorescence induction; biosensors

\section{Оцінка впливу каштанової мінуючої молі}

(Cameraria ohridella Deschka \& Dimič, 1986) на процеси фотосинтезу гіркокаштану звичайного (Aesculus hippocastanum Linnaeus, 1753)

\author{
К. К. Голобородько, А. А. Алексєєва, О. В. Селютіна, В. А. Горбань
}

Дніпровський національний університет імені Олеся Гончара, Дніпро, Украӥна

У статті представлено результати дослідження впливу живлення Cameraria ohridella Deschka \& Dimič, 1986 на стан фотосинтетичного апарату Aesculus hippocastanum. Для діагностики порушень фотосинтезу нативного хлорофілу у живому 
листку A. hippocastanum використано портативний флуорометр «Флоратест», розроблений Інститутом кібернетики імені В. М. Глушкова НАН України. Дослідження показали, що живлення гусені має вплив на всі параметри кривої індукції флуоресценції хлорофілу.

Ключові слова: вплив інвазійних видів; Cameraria ohridella; стійкість Aesculus hippocastanum; інтенсивність флуоресценції хлорофілу; біосенсори

\section{Вступ}

Каштанова мінуюча міль (Cameraria ohridella Deschka \& Dimič, 1986) - інвазійний фітофаг з родини Молейстрокаток (Gracillariidae Stainton, 1854), який ще на початку XXI ст. повністю заселив територію України (Zerova et al., 2007). C. ohridella - монофаг, трофічно пов'язаний iз гіркокаштаном звичайним (Aesculus hippocastanum Linnaeus, 1753). Своєю життєдіяльністю цей вид-інвайдер загрожує існуванню $A$. hippocastanum, заселяючи його дерева інколи на 95 \% (Holoborodko et al., 2009; Meshkova, Mikulina, 2009). Враховуючи, що гіркокаштан звичайний є однією із основних деревних порід населених місць в Україні, ця інвазія викликає посилений інтерес (Holoborodko et al., 2016). Отримано результати (Seliutina et al., 2020), що демонструють активізацію ферментативної антиоксидантної системи захисту A. hippocastanum на пошкоджуючу дію каштанової мінуючої молі, що дозволяє рослині вижити і завершити програму онтогенезу в несприятливих умовах. Найбільш вагомим для захисту клітин від мінера $є$ підвищення активності гваякол-пероксидази, що свідчить про посилення бар'єрних властивостей клітин (Shupranova et al., 2019).

3 іншого боку, залишається незрозумілим вплив C. ohridella на процеси фотосинтезу A. hippocastanum. Фотосинтез $\epsilon$ одним 3 найуразливіших до стресових чинників процесом, тому вагому інформацію про стан фотосинтетичного апарату рослини за дії на неї різних абіотичних та біотичних чинників можна дослідити методом флуоресценційного аналізу (Huang et al., 2012; Kargar et al., 2019; Pérez-Bueno et al., 2019). Флуоресценція хлорофілу - це показник, що дозволяе досліджувати в живих об'єктах проходження фотохімічних реакцій, пов'язаних 3 роботою фотосистеми II (ФСІІ), яка $\epsilon$ найбільш чутливою до факторів зовнішнього середовища. Результати досліджень інтенсивності флуоресценції хлорофілу (ІФХ) сприяють більш глибокому розумінню регуляторних механізмів, що забезпечують ефективне перетворення енергії в первинних і наступних стадіях фотосинтезу (Marques da Silva et al., 2020; Kalaji et al., 2017; Chen et al., 2019).

Метою нашого дослідження було встановити особливості впливу життєдіяльності $C$. ohridella на процес фотосинтезу $A$. hippocastanum із застосуванням методу оцінки ІФХ.

\section{Матеріали та методи досліджень}

Дослідження проведено в Ботанічному саду Дніпровського національного університету імені Олеся Гончара у червні 2019 р. Було обрано листки A. hippocastanum середньої формації по 5 шт. із освітленого та затіненого боку, обирали на річному вегетативному прирості з нижньої третини крони різної експозиції в суху погоду у період розвитку першої генерації $C$. ohridella (травень - червень 2019 р.) від чотирьох дерев гіркокаштану звичайного (всього досліджено 40 листків).

Для діагностики порушень фотосинтезу нативного хлорофілу у живому листку A. hippocastanum використано портативний флуорометр «Флоратест», розроблений Інститутом кібернетики імені В. М. Глушкова НАН України. Портативний флуорометр «Флоратест» складається 3 базового блоку 3 графічним рідиннокристалічним дисплеєм, кнопками управляння, виносного оптоелектронного сенсора, кабеля під'єднання до USB-порту персонального комп'ютера та мережевого адаптера. У виносному оптоелектронному сенсорі знаходиться світлодіод, який має максимальну інтенсивність випромінення на $\lambda=(470+20)$ нм. Показники опромінення в сенсорі: довжина хвилі опромінення $470+15$ нм; площа опроміненої плями не менше 15 мм² $^{2}$ освітленість в межах плями не менше 2,4 вт/м ${ }^{2}$. Показники приймання сигналу в оптоелектронному сенсорі: спектральний діапазон вимірювання інтенсивності флуоресценції від 670 до 800 нм; площа приймального вікна $9 \mathrm{mм}^{2}$; чутливість фотоприймача на $\lambda=650$ нм $0,45 \mathrm{~A} / \mathrm{W}$.

Спостереження проводили на живих листках A. hippocastanum, ушкоджених C. ohridella і не ушкоджених. Після початку дії світла інтенсивність флуоресценції хлорофілу (індукція флуоресценції або флуоресценція, індукована (наведена) світлом) починає істотно змінюватись 3 часом. Часова залежність інтенсивності флуоресценції хлорофілу (IФХ) має характерний вигляд кривої з одним чи кількома максимумами і отримала назву кривої ІФХ (крива Каутського) (рис. 1).

Форма цієї кривої досить чутлива до змін, які відбуваються у фотосинтетичному апараті рослин при адаптації до різних умов середовища, що стало основою широкого використання ефекту Каутського в дослідженні фотосинтезу (Antonova, Kovyrova, 2016).

\section{Результати та їх обговорення}

Застосувавши портативний флуорометр «Флоратест» на живих уражених $C$. ohridella та не уражених листках $A$. hippocastanum, ми отримали дані, які яскраво демонструють вплив живлення гусені мінера на інтенсивність флуоресценції хлорофілу (криву Каутського) (рис. 2).

У нормальних умовах рівень флуоресценції незначний (1-2 \% загального поглинутого світла), що свідчить про активне використання клітинами енергії поглинутого світла. Після освітлення адаптованих до темноти листків рослин спочатку протягом декількох секунд спостерігається різкий підйом інтенсивності флуоресценції хлорофілу - швидка фаза, а потім уже протягом декількох хвилин відбувається поступове зниження через певні стадії від повільної фази до стаціонарного рівня $\mathrm{F}_{\mathrm{St}}$ (Martinazzo et al., 2012).

Графік зміни флуоресценції від моменту початку освітлювання до досягнення стаціонарного рівня несе інформацію про стан фотосинтезуючого апарата листа рослини. Зміни O-I-D-P називають першою хвилею, або швидкою індукцією флуоресценції. Вона проходить за 1-3 с залежно від інтенсивності світла та інших факторів і спостерігається як у живих об'єктах, так і в ізольованих хлоропластах. Більш повільні зміни $\mathrm{P}-\mathrm{S}-\mathrm{M}-\mathrm{T}$ відомі як друга хвиля, або повільна індукція флуоресценції. Ці зміни проходять за час від декількох десятків секунд до декількох хвилин залежності від об'єкта та умов експерименту (Tseng, Chu, 2017).

У початковий момент часу всі канали фотосинтетичного переносу електронів відкриті й максимум енергії збудження електронів йде на фотосинтетичний процес. У цей період флуоресценція хлорофілу мінімальна i $\dddot{1 i}$ інтенсивність на кривій Каутського позначають буквою $\mathrm{F}$ з індексом "o", тобто $\mathrm{F}_{\mathrm{o}}$. Показник фонової флуоресценції $\left(\mathrm{F}_{\mathrm{o}}\right)$ характеризує 


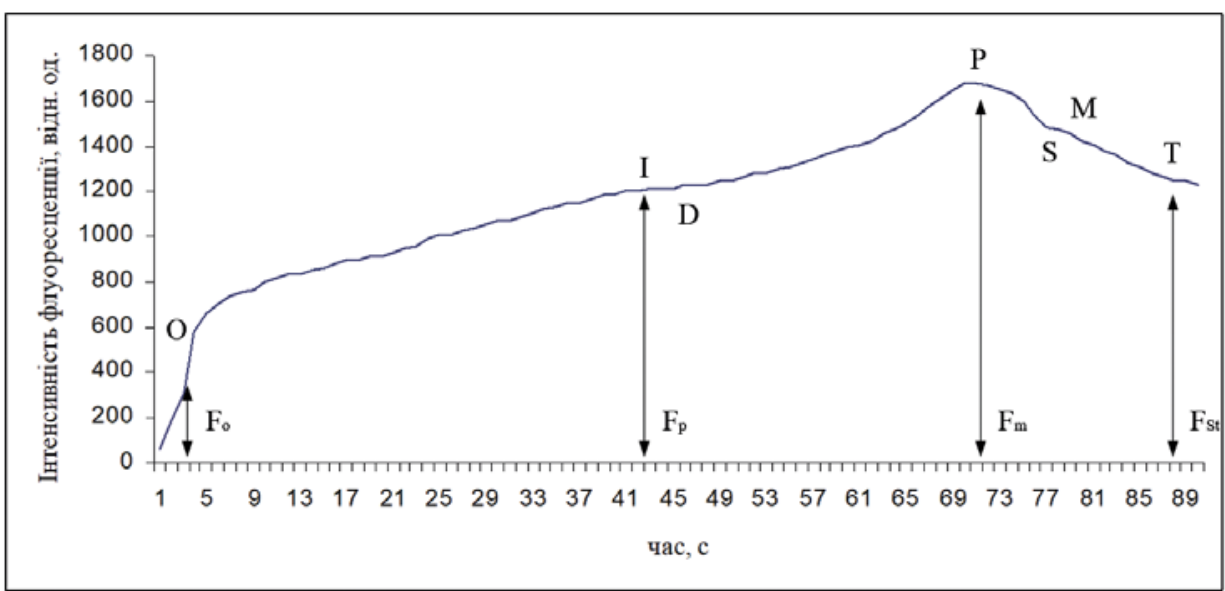

Рис. 1. Типова крива індукції флуоресценції хлорофілу:

$\mathrm{F}_{0}$ - початкове значення індукції флуоресценції після включення опромінення;

$\mathrm{F}_{\mathrm{p}}$ - значення індукції флуоресценції «плато»; $\mathrm{F}_{\mathrm{m}}$ - максимальне значення індукції флуоресценції;

$\mathrm{F}_{\mathrm{St}}$ - стаціонарне значення індукції флуоресценції після світлової адаптації листка рослини.

кількість неактивного хлорофілу, який не має функціонального зв'язку з реакційними центрами, тобто виступає початковим рівнем ІФХ. Він залежить від втрат енергії збудження під час міграції по пігментній матриці. Перехід $\mathrm{F}_{\mathrm{o}}-\mathrm{F}_{\mathrm{p}}$ пов'язаний зі зменшенням транспорту електронів. Він характеризує період теплової адаптації листка. При малому значенні періоду адаптації перехід має більшу крутість, а при великих значеннях він більш повільний (Rühle et al., 2018). Параметр $\mathrm{F}_{\mathrm{m}}$ вказує на найвищий рівень флуоресценції, який реєструється на індукційній кривій у вигляді максимуму. Всю ділянку $\mathrm{F}_{\mathrm{o}}-$ $\mathrm{F}_{\mathrm{m}}$ називають швидкою фазою флуоресценції. Повільна фаза індукції флуоресценції хлорофілу являє собою всі індукційні переходи після досягнення максимального значення (піку). Стаціонарний рівень флуоресценції $\left(\mathrm{F}_{\mathrm{St}}\right)$ характеризується динамічною рівновагою між процесами, які обумовлюють збільшення флуоресценції, та процесами, які призводять до ії зменшення. Із табл. 1 видно, що гусінь C. ohridella своїм живленням чинить вплив на всі основні параметри кривої індукції флуоресценції хлорофілу.

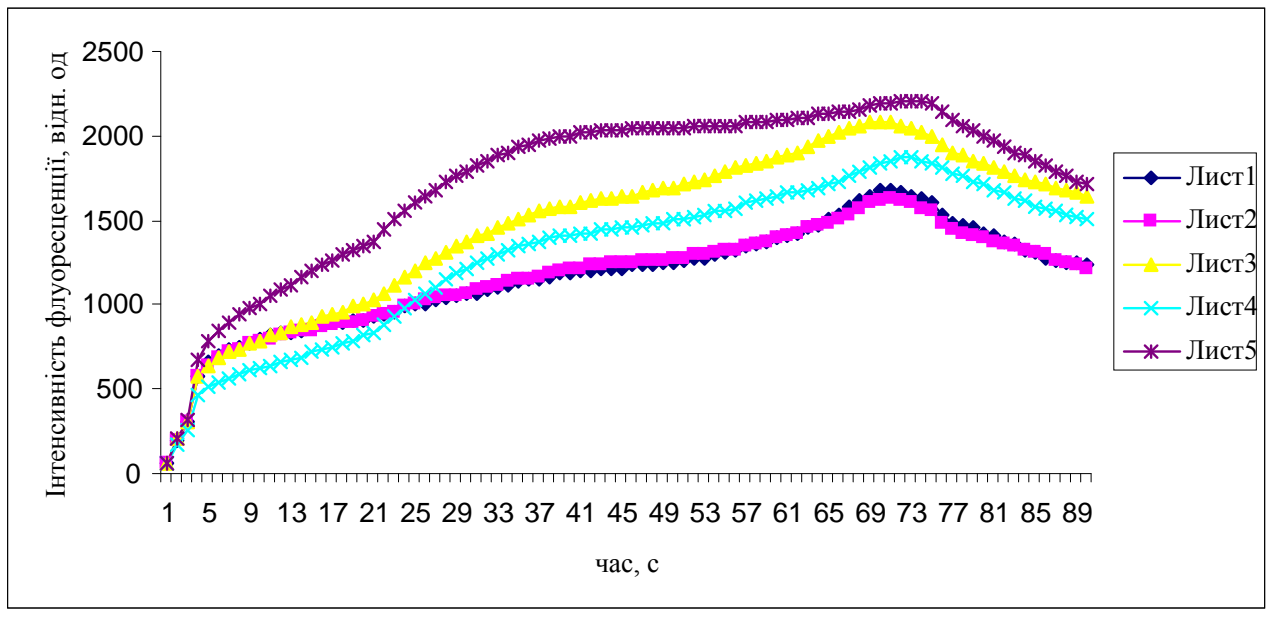

$a$

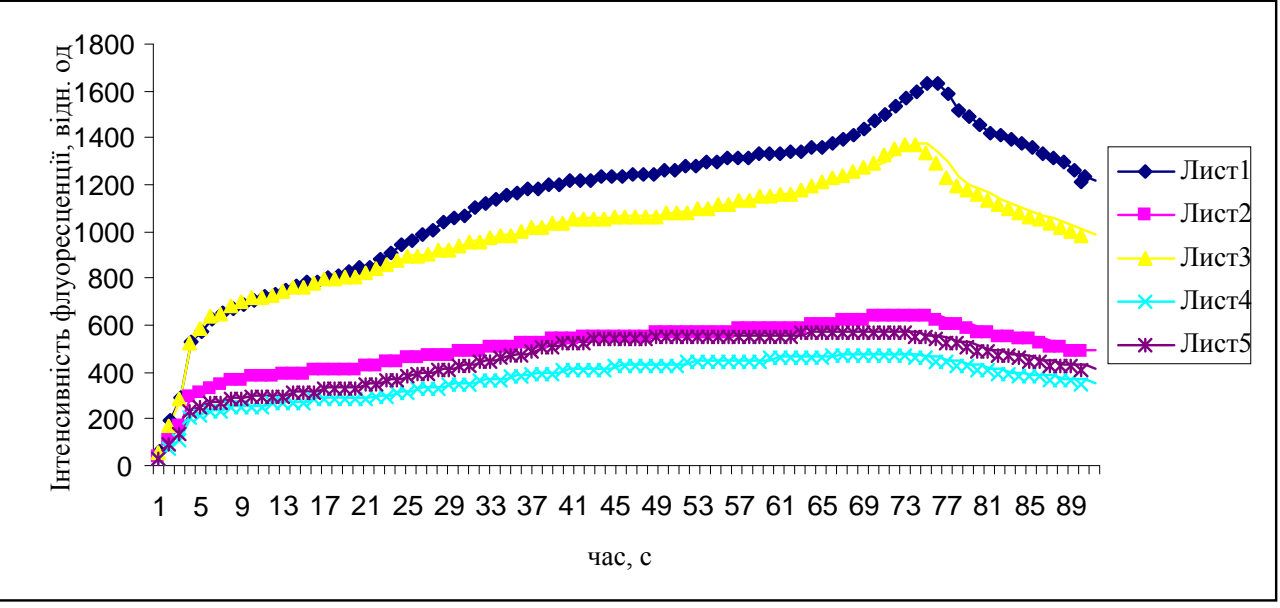

6

Рис. 2. Криві індукції флуоресценції хлорофілу (криві Каутського): $a$ - не ушкоджених листків (n=5); $\sigma$ - ушкоджених листків $(\mathrm{n}=5)$. 


\section{Таблиця 1}

Вплив живлення гусені $C$. ohridella на параметри кривих індукції флуоресценції хлорофілу A. hippocastanum (у відн. од.)

\begin{tabular}{ccc}
\hline Параметр & $\begin{array}{c}\text { Лист не } \\
\text { ушкоджений }\end{array}$ & $\begin{array}{c}\text { Лист } \\
\text { ушкоджений }\end{array}$ \\
\hline $\mathrm{F}_{\mathrm{o}}$ & 582 & 264 \\
$\mathrm{~F}_{\mathrm{p}}$ & 1460 & 722 \\
$\mathrm{~F}_{\mathrm{m}}$ & 1890 & 940 \\
$\mathrm{~F}_{\mathrm{St}}$ & 1530 & 746 \\
\hline
\end{tabular}

Для характеристики фотосинтетичного апарату в умовах стресу на рівні листка на етапі швидкої фази частіше використовують співвідношення варіабельної флуоресценції $\mathrm{F}_{\mathrm{v}}$ до максимального рівня $\mathrm{F}_{\mathrm{m}}$, яке вважається показником потенційної фотосинтетичної активності листка (Starychenko et al., 2016; Tseng, Chu, 2017). Варіабельність флуоресценції $\left(\mathrm{F}_{\mathrm{v}}\right)$ розраховується як різниця показників $\mathrm{F}_{\mathrm{m}}$ та $\mathrm{F}_{\mathrm{o}} \mathrm{i} \epsilon$ фізіологічним показником, який відображає дію екологічних та експериментальних чинників на рослину (Huliaieva et al., 2018). Однак цей параметр має деякі обмеження, оскільки він належить виключно до первинних фотохімічних процесів у ФСІІ і лише протягом перших 100-500 мс. Дія будь-якого несприятливого чинника (у нашому випадку це можливе ураження каштановою мінуючою міллю C. ohridella) зменшує атрагуючу здатність циклу Кальвіна, що призупиняє потік електронів, і реакційні центри переходять у неактивний (закритий) стан. При цьому поглинута енергія світла вже не може використовуватися в процесі фотосинтезу, і тому флуоресценція хлорофілу зростає в усьому часовому діапазоні реєстрації її індукційних змін.

\section{Висновки}

Установлено, що гусінь $C$. ohridella чинить істотний вплив на фотосинтетичний апарат A. hippocastanum. Цей вплив вдалося чітко визначити методом флуоресценційного аналізу, який ми здійснили портативним флуорометром «Флоратест». Аналіз кривих Каутського ураженого та не ураженого листків дозволив стверджувати, що живлення мінера істотно впливає на чотири основні параметри інтенсивності флуоресценції хлорофілу (ІФХ), а саме початкове значення IФХ, значення ІФХ «плато», максимальне значення ІФХ та стаціонарне значення ІФХ після світлової адаптації листка. Наші дослідження показали, що метод ІФХ дозволяє визначити загальний стан рослини в експресному режимі за допомогою оцінки основного процесу життедіяльності рослин - фотосинтезу. Аналіз параметрів флуоресценції хлорофілу $є$ потужним та ефективним інструментом визначення впливу фітофагів на організм рослини.

\section{References}

Antonova, G. V., Kovyrova O. V., 2016. Elementy metodyky vyprobuvan doslidnykh zrazkiv biosensora na testovykh kulturakh pid vplyvom diyi stresovykh faktoriv [Elements of methodical support for testing biosensor prototypes on the test plants under influence of stress factors]. Computer means, networks and systems, 15, 51-58.

Chen, X., Mo, X., Hu, S., Liu, S., 2019. Relationship between fluorescence yield and photochemical yield under water stress and intermediate light conditions. Journal of Experimental Botany, 70(1), 301-313.

Holoborodko K. K, Ryabka K. O, Zaitseva I. A, Kondratieva K. V., 2009. Poshyrennya ta suchasnyy stan kashtanovoyi minuyuchoyi moli (Cameraria ohridella Deschka \& Dimič, 1986) u m. Dnipropetrovsk [Distribution and current state of chestnut moth (Cameraria ohridella Deschka \& Dimič, 1986) in Dnepropetrovsk]. Problems of bioindication and ecology, 14 (2), 163-168 (in Ukrainian).
Holoborodko, K. K., Marenkov, O. M., Gorban, V. A., Voronkova, Y. S., 2016. The problem of assessing the viability of invasive species in the conditions of the steppe zone of Ukraine. Vìsn. Dnìpropetr. Unìv. Ser. Bìol. Ekol., $24(2), 466-472$.

Holoborodko, K. K., Rusynov, V. I., Seliutina, O. V., 2018. Invaziyni moli-strokatky (Gracillariidae Stainton, 1854) fauny Botanichnoho sadu Dniprovskoho natsionalnoho universytetu imeni Olesya Honchara [Invasive moths (Gracillariidae Stainton, 1854) of the fauna of the Botanical Garden of Oles Honchar Dnipro]. Issue of steppe forestry and forest reclamation of soils, 47, 87-91 (in Ukrainian).

Huang, Y., Thomson, S. J., Molin, W. T., Reddy, K. N., Yao, H., 2012. Early detection of soybean plant injury from glyphosate by measuring chlorophyll reflectance and fluorescence. Journal of Agricultural Science, 4(5), 117-124.

Huliaieva, H., Tokovenko, I., Maksin, V., Kaplunenko, V. Kalinichenko, A., 2018. Effect of nanoaquacitrates on physiological parameters of Fodder galega infected with phytoplasma. Ecol Chem Eng S., 25 (1), 153-168.

Kalaji, H. M., Schansker, G., Brestic, M., Bussotti, F., Calatayud, A. Ferroni, L., Goltsev, V., Guidi, L., Jajoo, A., Li, P., Losciale, P., Mishra, V. K., Misra, A. N., Nebauer, S. G., Pancaldi, S., Penella, C., Pollastrini, M., Suresh, K., Tambussi, E., Yanniccari, M., Zivcak, M., Cetner, M. D., Samborska, I. A., Stirbet, A., Olsovska, K., Kunderlikova, K., Shelonzek, H., Rusinowski, S., Baba, W., 2017. Frequently asked questions about chlorophyll fluorescence, the sequel. Photosynth Res., 132(1), 13-66.

Kargar, M., Ghorbani, R., Rashed Mohassel, M. H., Rastgoo, M. (2019). Chlorophyl fluorescence - a tool for quick identification of Accase and ALS inhibitor herbicides performance. Planta Daninha, 37, 1-10.

Marques da Silva, J., Figueiredo, A., Cunha, J., Eiras-Dias, J. E., Silva, S., Vanneschi, L., Mariano, P., 2020. Using rapid chlorophyll fluorescence transients to classify Vitis genotypes. Plants, 9, 174.

Martinazzo, E. G., Ramm, A., Bacarin, M. A., 2012. The chlorophyll a fluorescence as an indicator of the temperature stress in the leaves of Prunus persica. Braz. J. Plant Physiol., 24(4), 237-246.

Meshkova, V. L., Mikulina, I. M., 2009. Poshyrenist kashtanovoho minera (Cameraria ohridella Deschka and Dimic, 1986: Lepidoptera: Gracillariidae) u zelenykh nasadzhennyakh Kharkivshchyny [Prevalence of chestnut miner (Cameraria ohridella Deschka and Dimic, 1986: Lepidoptera: Gracillariidae) in green plantations of Kharkiv region]. Visnyk KHNAU. Seriya: Entomolohiya ta fitopatolohiya 8, 105-109 (in Ukrainian).

Pérez-Bueno, M. L, Pineda, M., Barón, M., 2019. Phenotyping plant responses to biotic stress by chlorophyll fluorescence imaging. Front. Plant Sci. 10, 1135.

Rühle, T., Reiter, B., Leister, D., 2018. Chlorophyll Fluorescence Video Imaging: A Versatile Tool for Identifying Factors Related to Photosynthesis. Front. Plant Sci., 9 (55), 1-13.

Seliutina, O. V., Shupranova, L. V., Holoborodko, K. K., Shulman, M. V., Bobylev, Y. P., 2020. Effect of Cameraria ohridella on accumulation of proteins, peroxidase activity and composition in Aesculus hippocastanum leaves. Regulatory Mechanisms in Biosystems. 11 (2), 299-304.

Shupranova, L. V., Holoborodko, K. K., Seliutina, O. V.. Pakhomov, O. Y., 2019. The influence of Cameraria ohridella (Lepidoptera, Gracillariidae) on the activity of the enzymatic antioxidant system of protection of the assimilating organs of Aesculus hippocastanum in an urbogenic environment. Biosyst. Divers., 2019, 27 (3), $238-243$

Starychenko, V., Golyk, L., Patyka, M. (2016). Fluorescence of chlorophyll pigment in leaves of soft winter wheat annual at different stages of organogenesis. Bulletin of Agricultural Science, 9, 25-29. 
Tseng Yi-Chin, Chu Shi-Wei., 2017. High spatio-temporalresolution detection of chlorophyll fuorescence dynamics from a single chloroplast with confocal imaging fuorometer. Plant Methods, (13) 43, 1-11.
Zerova, M. D., Nikitenko, G. N., Narolskiy, N. B., Gershenzon, Z. S., Sviridov, S. V., Lukash, O. V., Babidorich, M. M., 2007. Kashtanovaya miniruyushchaya mol' v Ukraine [Chestnut mining moth in Ukraine], Kiev, 90 (in Russian). 